\title{
The Correlation among Students' Vocabulary Mastery, Students' Creativity and Their Writing of Descriptive Texts
}

\author{
Baiq Aniatun Huliani
}

SMP Islam Al Badriyah, Indonesia

Correspondence: Baiq Aniatun Huliani, Indonesia. e-mail: aniatunhuliani@gmail.com

Received: Augustus 01, 2018

DOI: $10.29408 /$ veles.v3i1.1017.g738
Accepted: Februari 22, 2019 Online Published: April 15, 2019

URL: http://dx.doi.org/10.29408/veles.v3i1.1017.g738

\begin{abstract}
This research aimed at finding out the significant correlation among students' vocabulary mastery, students' creativity and their writing in descriptive texts for the eighth grade students of SMP Islam Al Badriyah in the school year 2017-2018. This research design was a correlational research with the population of the research was the eighth grade students of SMP Islam Al Badriyah and the sample was 23 students of class VIIIA which was chosen by using purposive sampling. To collect the data, the present researcher used fill the blank and essay test. In analyzing the data, she used SPSS statistics 22 for windows program. From the result of the partial correlation, it was found $r=.595$ at $p<.003$ for the correlation between vocabulary mastery and writing ability, the correlation between creativity and writing ability was found $r=.586$ at $p<.003$, the correlation between vocabulary mastery and creativity was found $r=.747$ at $p<.000$. While the correlation among students' vocabulary mastery, students' creativity and their writing ability was found $r=.611$ at $p<.003$. The value of significance level was less than 0.05. Meaning that, there was a significant correlation among students' vocabulary mastery, students' creativity and their writing in descriptive texts for the eighth grade students of SMP Islam Al Badriyah in the school year 2017-2018
\end{abstract}

Keywords: vocabulary mastery, creativity, writing ability

\section{Introduction}

English is an international that has significant role in many aspects such as politic, social, economy, education and so forth. In Indonesia, English is taught as a foreign language. It is programmed as one of compulsory subjects which is taught in almost all levels of education, especially at secondary and senior high schools. Even nowadays many primary schools stipulate English as a compulsory subject well. In learning English as a compulsory foreign language, there are four skills which must be mastered. Those are listening, speaking, reading, and writing. 
Writing can be said as a tool of communication instead of speaking, between reader and writer, do not take in the same place. According to Jumaily (2015, P. 29) "writing is the process of using symbols to communicate ideas". It is the effective way of communicating with others by expressing thoughts, feelings, and opinions.

One more thing that must be owned by the students in learning language, especially in learning foreign language is vocabulary. Vocabulary is the knowledge of meanings of words. According to Hornby (1995, p. 24), "vocabulary is the total number of words in a language; all the word known to a person or used in a particular book, or a list of words with their meanings especially on that accompanies a textbook in a foreign language". In learning English, vocabulary takes an important role. It is one of the elements that link the four skills of languages. Vocabulary is also useful in the process of building sentences. Someone cannot speak and build a sentence, without mastering it.

Vocabulary and creativity have their own function to make a good written. According to Nami, Marsooli, and Ashouri, $(2014$, p. 37) "creativity is the ability to make or bring to existence something new, whether a new solution to a problem, a new method or device or a new artistic object or form." Creativity is considered more of a tool or device rather than a gift or special ability. Without having creativity the writer cannot make his or her written text to be a great variety of reading and to make an interesting written from different situation.

Eventhough students realize the importance of writing and vocabulary in learning language, most of the students learn vocabulary passively because of several factors. Such as they think the teacher's explanation from meaning or definition, pronunciation, spelling, and grammatical functions are boring. So, language learners have nothing to do in a vocabulary learning section but to listen to their teacher. The other problem is the students do not want to do writing because of less of vocabulary and so forth. In this case, the creativity and mastering vocabulary are need to make a good learning process beside to make an innovative written texts. Without creativity and vocabulary, some written texts will be seen not interesting.

From the statement or some theories above, the present researcher concluded the vocabulary and the creativity cannot be separated in doing a good written. Vocabulary is the material to make a written text, while the creativity is the way to make a great written text. If the students want to make a great written, they should learn about vocabulary and the more important is they must have a good creativity.

Based on the problem and the statement of some theories above, the present researcher was curious to investigate about the correlation among students' vocabulary mastery, students' creativity and their writing in descriptive texts for the eighth graders of SMP Islam Al Badriyah in the school year 2017-2018.

Referring to the above theories and study, the problems were formulated in the form of questions as follows: 
1) Is there any significant correlation between students' vocabulary mastery and their writing in descriptive texts for the eighth grade students of SMP Islam Al Badriyah in the school year 2017-2018?

2) Is there any significant correlation between students' creativity and their writing in descriptive texts for the eighth grade students of SMP Islam Al Badriyah in the school year 2017-2018?

3) Is there any significant correlation between students' vocabulary mastery and their creativity for the eighth grade students of SMP Islam Al Badriyah in the school year 2017-2018?

4) Is there any significant correlation among students' vocabulary mastery, students' creativity, and their writing in descriptive texts for the eighth grade students of SMP Islam Al Badriyah in the school year 2017-2018?

\section{Method}

This study was categorized as a correlation study which used correlation research design. In this case the present researcher tried to find out the correlation among students' vocabulary mastery, students' creativity and their writing in descriptive texts. In the process of conducting the study, the present researcher gave the instructions and prepared a test in case of vocabulary, creativity, and writing material. When assessing a correlation coefficient, one must take into account the population from which the sample was drawn, the shape of the distribution, the sample size, and it was statistical and partial significance.

\subsection{Participants}

The populations of the study in this research was the entire of the eighth grade students of SMP Islam Al Badriyah in the school year 2017-2018 which consist of two classes, those were class VIII-A and VIII-B with the number of students were 23 for class A, and 22 students for class B.

In this research, the present researcher determined some characteristics of the students that would be chosen as the sample of the research by using purposive sampling. Those characteristics are the student is the member of English quarantine in the school, the student able to memorize at least 50 vocabularies, the student can make an interesting story and the student can make a creative thing. Then, the present researcher took class VIIIA to be her samples based on the characteristics.

\subsection{Data Collection}

\subsubsection{Instrument of Collecting Data}

In this research, the present researcher used the subjective test in form of essay to measure the students' writing ability in descriptive for the eighth grade students of SMP Islam Al Badriyah in the school year 2017-2018. The material of the test was fill in the blank for the creativity and writing an essay of descriptive texts relate to the picture for the vocabulary and writing test. 


\subsubsection{Techniques for Collecting Data}

There were two kinds of test that used to obtain the data, those written test and fill the blank tests. The time allocated for written test was thirty minutes for each sample. In doing the test, the present researcher applied some steps:

a) Before giving the test to the sample, the present researcher gave an explanation about the test that would be given to the students.

b) When the students understood about the instruction, the present researcher asked the students to fill the correct answer for the questions of creativity test. Then the students made an essay related to the choices picture for vocabulary and writing test.

c) The present researcher analyzed the students' vocabulary, students' creativity, and their writing tests.

\subsection{Data Analysis}

For the data analysis, result of the research was analyzed descriptively. The present researcher analyzed the descriptive statistic and statistics for testing hypothesis.

\subsubsection{Descriptive statistics}

To obtain the data, the present researcher used descriptive statistics. In this case, the present researcher used SPSS statistics 22 for windows to find mean and standard deviation.

\subsubsection{Statistics for Testing Hypothesis}

Hypothesis show temporal answers that have to be proved. This was proposed to know the correlation among the variables. To examine the correlation among vocabulary, creativity, and writing ability of the students, the present researcher used partial correlation by using SPSS Statistics 22 for windows.

\section{Findings}

In this part, the present researcher found the descriptive statistics about the correlation among students' vocabulary mastery, students' creativity and their writing in descriptive texts for the eighth grade students of SMP Islam Al Badriyah. From the descriptive statistics output SPSS Statistics 22 for windows was found Mean and Std. Deviation of each variable with $\mathrm{N}=23$. For writing ability it was found that Mean $=65.65$ and Std. Deviation $=6.96$ with $\mathrm{N}=23$. For vocabulary mastery it was found that Mean $=81.96$ and Std. Deviation $=5.16$ with $N=23$. And for creativity it was found that Mean $=80.65$ while Std. Deviation $=4.07$ with $\mathrm{N}=23$.

In hypothesis testing, the partial correlation of SPSS Statistics 22 for windows was used to examine the correlation among vocabulary, creativity, and writing ability of the students. By examining the value of the significant level, it could be decided whether correlation coefficient were accepted. As the result from the partial correlation output, the pearson $\mathrm{r}$ was .611 at $\mathrm{p}<.003$ which is lower than 0.5 for vocabulary mastery and creativity with writing ability was constant. It meant that the first alternative ( $\mathrm{Ha})$ was accepted based on standard level significance level in SPSS. 


\section{Discussion}

This research was aimed at finding out the significant correlation among students' vocabulary mastery, students' creativity and their writing in descriptive text for the eighth grade students of SMP Islam Al Badriyah in the school year 2017-2018.

Based on the result of this research, it shows that the score of the students' vocabulary mastery and creativity was higher than their writing ability, which meant that there was significant correlation of those variables. This result is consonant with some theories about this research. In 1997, Schmitt emphasized that lexical knowledge is central to communicative competence and to the acquisition of a second language. In other side, Munandar (2012) explained that creativity as a general ability to create new relationship between elements which have been provided. While Ontario (2005) stated that writing is powerful instrument for students to express their thoughts, feeling, and judgments.

By seeing the theories above, it indicated that there is a significant correlation among vocabulary mastery, creativity and writing ability of the students. In doing writing, creativity and vocabulary mastery are really needed because without sufficient vocabulary students cannot understand others or express their own ideas, it is a central to English language teaching. While creativity is needed to create and to connect some vocabulary to be new words or new sentences which is express through writing. By mastering vocabulary and creativity, the students can be easily in doing writing.

The finding of this research was supports the relevant previous studies also. In Yuyun's research reveal that there was a significant correlation between students' vocabulary mastery and their writing ability in descriptive texts which was conduct at SMP Islam Sudirman 1 Bancak Semarang District in the Academic year of 2016-2017 with the population was 26 students. To collect the data she used Pearson Product Moment correlation.

Setyaningrum's research showed also the result of the students' creativity in writing ability by using picture series which was indicated that the picture series could improve the students' creativity in writing ability. This research was conduct at SMP Cokroaminoto Banjarnegara in Academic Year 2011-2012 with the subject was 22 students and collecting data through observation, questionnaire, and interview. While in analyzing data, she used class percentage and interrogative qualitative analysis.

The result of both of the relevant previous studies above showed that there was a significant correlation among vocabulary mastery, creativity and writing ability which is same with the result of the present researcher research. Vocabularies and creativities cannot be separated in doing a good written. Both of them have correlation each other in writing process. Vocabulary is the material to make a written text, while the creativity is the way to make a great written text. 


\section{Conclusions}

On the basis of the results, some answers of the research questions can be concluded that there was significant correlation between vocabulary mastery and writing ability for the eighth grade students of SMP Islam Al Badriyah in the school year $2017 / 2018$ with the correlation coefficient $r$ was .595 at $p<.003$ which is lower than 0.05 (as the standard level significance level in SPSS) at two tail. In addition, there was significant correlation between creativity and writing ability for the eighth grade students of SMP Islam Al Badriyah in the school year 2017/2018 with the correlation coefficient $r$ was .586 at $p<.003$ which is lower than 0.05 (as the standard level significance level in SPSS) at two tail.

There was significant correlation between vocabulary mastery and creativity for the eighth grade students of SMP Islam Al Badriyah in the school year 2017/2018 with the correlation coefficient $r$ was .747 at $p<.000$ which is lower than 0.05 (as the standard level significance level in SPSS) at two tail. Furthermore, there was significant correlation between vocabulary mastery, creativity and writing ability for the eighth grade students of SMP Islam Al Badriyah in the school year 2017/2018 with the correlation coefficient $r$ was .611 at $\mathrm{p}<.003$ which is lower than 0.05 (as the standard level significance level in SPSS) at two tail.

\section{References}

Ary, D., Jacobs, C. L., Sorensen, C.,\&Razavieh, A. (2010). Introduction to research education. London: Wardswoth. Cengange Learning.

Adela, G., Lai, Yu-ling. (2005). Teaching vocabulary learning strategies: awareness, beliefs, and practices. a survey of Taiwanese EFL senior high school teachers. Taiwan: University of Essex.

Al Jumaily, Samir. (2015). Improving my students' writing skill: An intensive course for ESL learners by using process-approach to writing with the assistance of computer word processor. International Journal of English Language Teaching, 2(1), 29-35.

Alqahtani, Mofareh. (2015). The importance of vocabulary in language learning and how to be taught.international Journal of Teaching and Education. 3 (3), 21-34.

Anoiko. (2011). Creativity. Bandung: Alfa Beta

Azizah, Yuyun. (2017).The correlation between students' vocabulary mastery and their writing ability in descriptive text (a study for the seventh grade students of SMP Islam Sudirman 1 Bancak Semarang district in the academic year 2016-2017. Unublished undergraduate Thesis IAIN, Salatiga.

Brown, H. Douglas. (2004). Language assessment: Principles and classroom practices. USA: Longman.

Brown, J. D. (2007). Multiple views of L1 writing score reliability. Second Language Studies, 25(2), 1-31. 
Dewi. C.L. (2017). Improving students' creativity in writing recount text by using mind mapping. Jurnal Managemen Pendidikan, 12(2), 128-138.

Fachrurrazy, M.A, P.hD. (2011). Teaching English as aforeign language for teacher in Indonesia. University of Malang.

Franken page 396. Retrieved March, 29 ${ }^{\text {th }}$ 2018, from http://www.csun.edu/ vcpsy00h/creativity/define.htm

Harmer, Jeremy. (2001). How to teach English. Malaysia: Longman

Hiebert. E.H, and Kamil. M. L. (Ed). (2005). Teaching and learning vocabulary: Bring research to practice. New Jersey: Lawrence Erlbaum Associates.

Hornby, A.S, (1995). Oxford advanced learner's dictionary. Walton Street: Oxford University Press.

http://www.reference.com/browse/creativity. Retrieved March, 29th 2018, $12.17 \mathrm{pm}$.

Jacobs, Holly S. (1981). Testing ESL composition: A practical Approach. Massachusetts: Newburry House Publisher, Inc.

Juniardi, Lalu Ahdiat. (2014). The correlation between students' vocabulary mastery and their ability in translating English into Indonesian for the eighth grade of SMPN 2 Sukamulia in the school year 2013-2014. Unpublished undergraduate Thesis, Hamzanwadi University, Nusa Tenggara Barat, Indonesia.

Maslow, A.H, (1970). Motivation and personality. English: Harper \& Row Publisher, Inc.

Moedjito.(2016). Basic statistic for research in language education. Suakarta: Yuma Pustaka

Nami, Yaghoob., Marsooli, Hosein., \& Ashouri, Maral. (2014). The relationship between creativity and academic achievement. Procedia-Social and Behavioral Sciences. 114, 36-39 (2014).

Ontario. (2014). A guide to effective instruction in writing for kinder garden grade. Ontario Education.

Peha, Steve. (2003). Assessing writing. Website: www.ttms.org.

Schmitt, Norbert. (1997). Using a word knowledge framework to research vocabulary University of Nottingham.

Setyaningrum, Endah. (2012). Improving students' creativity in writing procedure text using picture series at VII grade of SMP Cokroaminoto Banjarnegara in academic year 2011-2012. Unpublished uundergraduate Thesis, Muhammadiyah University, Purwokerto.

Skinner, B.F, (2014), Science and human behavior. Cambridge: pearson Education, Inc. 